\title{
Infection patterns of the chytrid fungus, Batrachochytrium dendrobatidis, on anuran assemblages in agro-ecosystems from Buenos Aires Province, Argentina
}

\author{
M. Gabriela Agostini ${ }^{1}$ and Patricia A. Burrowes ${ }^{2}$ \\ ${ }^{1}$ Grupo de Estudios sobre Biodiversidad en Agroecosistemas, Instituto de Ecología, Genética y Evolución de Buenos Aires \\ (UBA-CONICET), Pabellón II Ciudad Universitaria, C1428EHA, Buenos Aires, Argentina. E-mail: gabrielaagostini18@ \\ gmail.com. \\ ${ }^{2}$ Department of Biology, University of Puerto Rico, P. O. Box 23360, San Juan, Puerto Rico. E-mail: paburrowes@uprrp.edu.
}

\begin{abstract}
Infection patterns of the chytrid fungus, Batrachochytrium dendrobatidis, on anuran assemblages in agro-ecosystems from Buenos Aires Province, Argentina. The disease chytridiomycosis, caused by the pathogenic chytrid fungus Batrachochytrium dendrobatidis $(B d)$, is linked to extinctions and declines of amphibians. Additionally, in the context of amphibian decline, the habitat loss related to agricultural landscapes is likely the single most important human activity affecting lowland amphibian populations. To assess the impact of anthropogenic land use on anuran response to $B d$, infection patterns in several ponds from cultivated (CA) and uncultivated areas (UCA) were studied. Four anuran species (Rhinella fernandezae [Bufonidae]; juvenile and adult of Leptodactylus latrans [Leptodactylidae]; and the hylids Hypsiboas pulchellus and Pseudis minuta) were monitored and tissue samples were collected for $B d$ diagnosis and quantification. All species tested positive for $B d$, but anurans inhabiting the UCA were twice more likely to be infected than those in the CA. Prevalence and infection level were significantly higher in the UCA, suggesting that vulnerability to $B d$ is associated with land use in agroecosystems. At the assemblage-level, the infection patterns also differed among species, and those with aquatic habitats (L. latrans and P. minuta) had high prevalence and infection levels of $B d$. Juvenile stages of $L$. latrans had higher prevalence and infection level than adults in both study areas. This work contributes to our understanding of anthropogenic effects on host-pathogen relationships, particularly on the effect of $B d$ on anuran assemblages under different levels of agricultural impact.
\end{abstract}

Keywords: chytridiomycosis, Hypsiboas pulchellus, land-use change, Leptodactylus latrans, Pseudis minuta, Rhinella fernandezae. 


\begin{abstract}
Resumo
Padrões de infecção do fungo quitrídeo, Batrachochytrium dendrobatidis, em assembleias de anuros de agro-ecossistemas da Província de Buenos Aires, Argentina. A quitridiomicose, causada pelo fungo quitrídeo patogênico Batrachochytrium dendrobatidis $(B d)$, está ligada a extinções e declínios de anfíbios. Adicionalmente, no contexto dos declínios de anfíbios, a perda de habitat relacionada às paisagens agrícolas é provavelmente a atividade humana isolada mais importante que afeta populações de anfíbios de planícies. Para avaliar o impacto do uso antropogênico da terra sobre a resposta dos anuros ao $B d$, foram estudados os padrões de infecção em diversas lagoas de áreas cultivadas (CA) e incultas (UCA). Quatro espécies de anuros (Rhinella fernandezae [Bufonidae]; juvenis e adultos de Leptodactylus latrans [Leptodactylidae]; e os hilídeos Hypsiboas pulchellus e Pseudis minuta) foram monitoradas e amostras de tecido foram coletadas para diagnose e quantificação do $B d$. Todas as espécies mostraram-se infectadas pelo $B d$, mas os anuros de UCA tiveram probabilidade duas vezes maior de estar infectadas do que aquelas de CA. A prevalência e o nível de infecção foram significativamente maiores nas UCA, sugerindo que a vulnerabilidade ao $B d$ está associada ao uso da terra em agro-ecossistemas. No nível de assembleias, os padrões de infecção também diferiram entre as espécies, e aquelas de habitats aquáticos (L. latrans and $P$. minuta) tiveram alta prevalência e altos níveis de infecção de $B d$. Os estágios juvenis de $L$. latrans tiveram maior prevalência e maior nível de infecção do que os adultos em ambas as áreas de estudo. Este trabalho contribui para o conhecimento dos efeitos antropogênicos sobre as relações hospedeiropatógeno, particularmente sobre o efeito do $B d$ em assembleias de anuros sujeitas a diferentes níveis de impacto agrícola.
\end{abstract}

Palavras-chave: $B d$, Hypsiboas pulchellus, Leptodactylus latrans, mudança no uso da terra, Pseudis minuta, quitridiomicoses, Rhinella fernandezae.

\section{Introduction}

Chytridiomycosis is an amphibian skin disease caused by the aquatic chytrid fungus Batrachochytrium dendrobatidis $(B d)$, which has been implicated in amphibian declines and extinctions around the world (Berger et al. 1998, Burrowes et al. 2004, 2008, Lips et al. 2006, Cheng et al. 2011). Additionally, in the context of amphibian decline, habitat loss related to agricultural landscapes is likely the single most important human activity that affects lowland amphibian populations (Gallant et al. 2007). Nonetheless, surprisingly few studies have examined patterns of $B d$ infection in agroecosystems or areas that differed in their agricultural disturbance levels (Murrieta-Galindo et al. 2014).

Environmental stressors associated with agricultural disturbance, such as pesticides, can suppress the immune system and increase disease susceptibility (Davidson et al. 2007, Wise et al. 2014). However, recent studies have demonstrated that pesticides (under controlled laboratory conditions) can produce negative effects on growth and survival of $B d$, but such effects depend on the pesticide type and timing of exposure (Hanlon and Parris 2012, McMahon et al. 2013). In addition, habitat loss is negatively associated with $B d$ infection in tropical amphibians (Becker and Zamudio 2011) and abiotic factors, such as temperature and precipitation, alter physiological processes of hosts and pathogens, affecting $B d$-amphibian dynamics (Carey and Alexander 2003, Piotrowski et al. 2004, Rohr et al. 2008, Longo et al. 2010, Murray et al. 2013).

The amount of land dedicated to agricultural activities in Argentina has increased dramatically in the last 20 years since cultivation of genetically 
modified organisms (GMO) has been adopted (Bindraban et al. 2009). Buenos Aires Province is located within Argentine Pampas and is the area that has undergone the most modification (Viglizzo et al. 2001). The Argentine Pampas is one of the richest agricultural areas of the world, covering about 52 million hectares of productive organic soils that originally were grasslands (Solbrig 1997, Soriano 1991). Soybeans crops replaced lands for livestock, expanding the agricultural frontier to areas previously not suitable for cultivation. Significant impacts have been reported in areas of accelerated replacement; these changes are mainly associated with pesticide pollution of wetlands and aquifers, and habitat loss (Herrera et al. 2013). Studies conducted in croplands of this region have documented that members of amphibian populations have debilitated bodies, enzymatic alterations (Brodeur et al. 2011), and high prevalences of abnormalities (Agostini et al. 2013). Additionally, application of common pesticides cause lethal and sublethal effects on tadpoles (Agostini et al. 2009, Agostini 2013). This region has also been predicted to be the most suitable for the occurrence of $B d$ (Ghirardi et al. 2011).

As mentioned above, a growing body of literature suggests that factors influencing $B d$ amphibian dynamics are varied, complex and context-dependent, and involve multiple natural and anthropogenic stressors (Fisher et al. 2009, Blaustein et al. 2012, Doddington et al. 2013). To facilitate our understanding of these issues, we need studies focused on the patterns of $B d$ infection occurring in environments affected by agricultural activities. We assessed whether the patterns of $B d$ infection varied among anuran assemblages in agro-ecosystems with different land uses (cultivated areas where pesticides were applied and uncultivated areas). Based on previous studies conducted in the region showing several impacts in anurans inhabiting crop lands, we predicted high prevalence and level of $B d$ infection in cultivated areas.

\section{Materials and Methods}

\section{Study Site}

The Pampean Ecoregion is characterized by grassland vegetation (Cabrera and Willink 1973). The climate is temperate humid, with cold winters and long warm summers (average temperatures $9.9^{\circ} \mathrm{C}$ and $22.8^{\circ} \mathrm{C}$ respectively). The annual rainfall varies between 1000 and 1100 $\mathrm{mm}$. The seasonal distribution of rainfall is fairly regular, although a significant decrease occurs in winter (Hurtado et al. 2006). In our study area, the dominant landscape is a complex mixture of different crops (vegetables, soybeans, corn and wheat) and grasslands for livestock. These activities have affected several aquatic habitats (including ponds, wetlands, and streams) related to agro-ecosystems that were studied (Ronco et al. 2008, Mugni et al. 2010, 2011, Brodeur et al. 2011, Agostini 2013, Agostini et al. 2013)

We studied anuran assemblages in six agroecosystems that contained several temporary ponds located in areas that differed in their agricultural disturbance level (Figure 1). The first is an area extensively cultivated with soybeans and wheat (CA); it includes three agroecosystems (1-3) where several pesticides (glyphosate, endosulfan, chlorpyrifos and cypermethrin) were repeatedly applied during the study period (Agostini et al. 2013). The second is an uncultivated area (UCA) that includes three agro-ecosystems (4-6) of natural grasslands used for low density dairy livestock. The cattle remain in the upper plots most of the year, thereby producing very little disturbance to the lower ponds where this study was conducted. Pesticides were not applied and the most commonly used were not detected (Agostini et al. 2013).

\section{Anuran Survey and Bd Detection}

We studied anuran breeding assemblages of four species that are common in the region. Although adults have different habitat requi- 


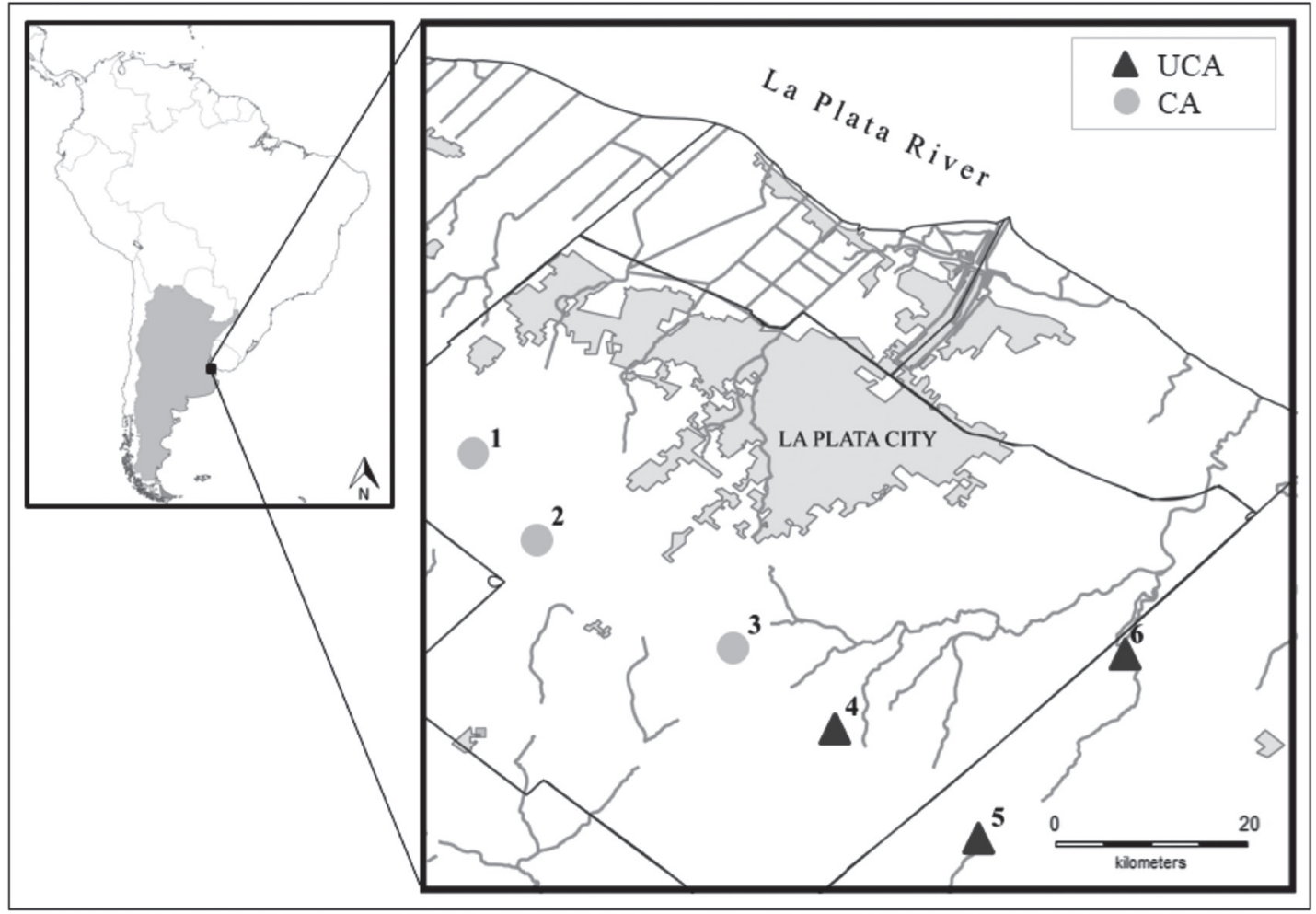

Figure 1. Study area. CA 1-3: agro-ecosystems from cultivated area. UCA: 4-6: agro-ecosystems from uncultivated area. The grey surface indicates urban zones (La Plata, Berisso, and Ensenada cities).

rements, all species reproduce in temporary and semi-temporary ponds and their larvae are completely aquatic. Rhinella fernandezae (Bufonidae) is a terrestrial burrowing toad that congregates in ponds to breed. Leptodactylus latrans (Leptodactylidae) is a semi-aquatic frog. Hypsiboas pulchellus (Hylidae) is a tree frog and Pseudis minuta (Hylidae) is an aquatic frog (Cei 1980). We also were interested in determining patterns of $B d$ infection in juveniles. For this, we chose $L$. latrans because it was the only species that reproduces in ponds in both study areas (CA and UCA), thereby allowing us to compare results from areas of different land uses. Field work was conducted in February 2010 and 2011, and March 2012. We monitored anurans by conducting visual-encounter surveys in each breeding pond along three, $30 \times 2 \mathrm{~m}$ transects (Heyer et al. 1994). We photographed and marked (by toe-clipping) each anuran for future population-density estimates (Agostini 2013) and to prevent sampling the same individual more than once. To avoid cross-contamination, we collected frogs individually using clean plastic bags and gloves. The following data were recorded for each individual sampled: body size (snout-vent length, SVL), weight, age class, and sex; in addition, we diagnosed each anuran for clinical symptoms of chytridiomycosis, such as erythema, sloughing of ventral skin, lethargy and delayed righting reflex (Berger et al. 2005) before returning it to the environment. 
In each survey, we measured the physiochemical parameters of the ponds. Temperature, dissolved oxygen (DO), conductivity, and $\mathrm{pH}$ were measured in situ with a Lutron YK series 2000 multimeter. We also estimated the surface area of the pond and measured its average depth.

We collected tissue samples from anurans by swabbing (10 strokes) the ventral pelvic-patch region, thighs, and palmar/plantar surfaces of the hands and feet, respectively, in adults and juveniles (Hyatt et al. 2007). DNA for diagnosis of $B d$ infection was extracted from swabs using a Prep-Man Ultra assay (Hyatt et al. 2007), and $B d$ loads were quantified via a Taqman qPCR method with a Stratagene MX 3005P system (Boyle et al. 2004). We ran every assay with a triplicate set of $B d$ standards corresponding to $0.1,1,10,100$, and 1000 zoospore equivalents, three negative controls, and an internal positive control (ABI Cat $\mathrm{N}^{\circ} 4308$ 323) to test for potential contamination. The standards for quantification of $B d$ genomic equivalents were prepared by extracting the DNA of zoospores in the Puerto Rican $B d$ strain (JEL 427), which has 65 ITS-1/5.8 copy numbers per zoospore (Longo et al. 2013), and following Boyle et al. (2004).

\section{Statistical Analysis}

To identify the physical and chemical variables of the ponds that might affect the patters of $B d$ infection, we evaluated differences among ponds through time by using factorial ANOVA (Crawley 2007). For each model we considered the physiochemical (temperature, DO, conductivity, and $\mathrm{pH}$ ) and physical parameters (area and average depth) as response variables. The pond identity and time (years) were considered as fixed factors. A Tukey's HSD post hoc analysis was carried out to test for differences among the ponds and years and species.

To assess the infection patterns of $B d$ in the anuran assemblages, we measured prevalence of $B d$ (number of individuals infected/total sampled) and the infection level reported as number of $B d$ genomic equivalents. To test the effects of study area and time (years) on the infection pattern of $B d$, we employed generalized linear mixed models (GLMM) (Zuur et al. 2009). We considered as fixed effects: study area (CA and UCA), species ( $R$. fernandezae, L. latrans, and $H$. pulchellus), and year (2010, 2011, and 2012). Additionally, we included in the models those physiochemical parameters and size variables that varied significantly among study ponds and/or years. We included the sites (CA 1-3 and UCA 4-6) in the models as a random effect. A GLMM with binomial family distribution and cbind response terms (number $B d$-positive, number $B d$-negative) was used to test for differences in prevalence of $B d$, but for the infection level, we applied a GLMM with Gaussian family distribution. The significance of random effects for both models was evaluated with a likelihood ratio (LR), and we used the backward-selection procedure to remove nonsignificant terms from each model one by one, in decreasing order of probability. A Tukey's HSD post hoc analysis was also conducted to test for differences in the prevalence of $B d$ and infection level among the years and species. Last, we applied odds ratio (OR) statistics to estimate the probability of having $B d$ at the different sites (VassarStats 2014).

Because Pseudis minuta was not found in any breeding ponds from the CA, we excluded this species from the models used for comparing patterns of $B d$ infection in agro-ecosystems with different land use. To analyze differences in prevalence and level of $B d$ infection among species within the UCA (including $P$. minuta) we used the same statistical procedure above, but removing data from CA.

Leptodactylus latrans was the only species for which we monitored $B d$ in juvenile and adult stages. We performed a linear regression with a dummy variable (Zar 2010) to assess potential relationships between size (SVL) and infection level of $B d$. We considered the study area as auxiliary (dummy) variable.

All statistical analyses were carried out with R software, Version 3.1-108 (R Development 
Core Team 2014). All tests were two-tailed, and differences were considered significant at $p<$ 0.05 .

\section{Results}

The factorial ANOVAs conducted to analyze physicochemical parameters and morphometric variables among studied ponds over time did not show significant differences $(p>0.05)$ in any of the tested variables, except in the temperature. This parameter varied significantly between the years $(F=6.98, d f=1.61, p=0.01)$ and the values increased significantly in 2011 and 2012 (Tukey's post hoc analysis: $p<0.05$ ). Based on this result we added this parameters to the GLMM for testing the effects of study area and time (years) on the prevalence and level of $B d$ infection. Values of physicochemical parameters and morphometric variables are shown in Table 1.

All of the anuran species studied from both the cultivated area (CA) and the uncultivated area (UCA) were $B d$-positive. The overall (assemblage-level) prevalence of $B d$ was 0.38 (170/448) for CA and 0.55 (280/510) for UCA. The GLMM random effect (sites) was not statistically significant according to the LR test
(= 0.34, $d f=1, p=0.56)$. After correcting for random effects, $B d$ prevalence was significantly different between UCA and CA $(Z=-3.93, p<$ 0.05 ) being higher at the UCA (Table 2). The model also showed significant differences for $B d$ prevalence between years $(Z=6.65, p<0.05)$ and species $(Z=5.29, p<0.05)$. The prevalence of $B d$ detected in 2010 was significantly higher (Tukey's post hoc analysis: $p<0.05$ ) than in 2011 and 2012 (Table 2), whereas Leptodactylus latrans had a significantly higher prevalence than the other species $(p<0.05)$ (Figure 2). Regarding to the physiochemical parameters, the temperature of the water ponds had a significant effect on $B d$ prevalence $(Z=-2.53, p<0.05)$. Odds ratio analysis predicted that anurans inhabiting cultivated area (CA) are twice more likely to get infected by $B d$ than anurans in uncultivated area (UCA) $[O R=1.99,95 \%$ CI (1.53-2.58), $p<0.05]$.

The GLMM used to analyze differences in the infection level did not show any significant differences for the random effect $(=2.17, d f=1$, $p=0.14$ ), which was removed from the model. The infection level was also significantly higher in UCA than in CA $(F=9.87, d f=1-911, p<$ $0.05)$ with a marked effect of time (years) for this variable as well $(F=15.24, d f=2-911, p<$

Table 1. Physiochemical parameters of the ponds (data are given as mean values and standard errors) in each study area and year. $\mathrm{CA}=$ cultivated area; $\mathrm{UCA}=$ uncultivated area.

\begin{tabular}{lcccccc}
\hline Year & $\begin{array}{c}\text { Temperature } \\
\left({ }^{\circ} \mathbf{C}\right)\end{array}$ & $\begin{array}{c}\text { Dissolved } \\
\text { Oxygen }(\mathbf{m g} / \mathbf{L})\end{array}$ & $\mathbf{p H}$ & $\begin{array}{c}\text { Conductivity } \\
(\mathbf{m S} / \mathbf{c m})\end{array}$ & Area $\left(\mathbf{m}^{2}\right)$ & $\begin{array}{c}\text { Depth Average } \\
(\mathbf{c m})\end{array}$ \\
\hline $\mathbf{C A}$ & & & & & & \\
2010 & $18.1 \pm 1.3$ & $9.4 \pm 1.2$ & $7.31 \pm 0.23$ & $0.23 \pm 0.15$ & $162.81 \pm 52.23$ & $52.7 \pm 12.1$ \\
2011 & $23.6 \pm 1.9$ & $10.1 \pm 0.8$ & $7.25 \pm 0.39$ & $0.18 \pm 0.19$ & $129.57 \pm 40.62$ & $49.3 \pm 9.8$ \\
2012 & $23.3 \pm 2.1$ & $9.7 \pm 1.4$ & $7.12 \pm 0.36$ & $0.17 \pm 0.12$ & $132.31 \pm 41.19$ & $47.9 \pm 11.5$ \\
UCA & & & & & & \\
2010 & $17.7 \pm 2.2$ & $9.1 \pm 0.9$ & $7.29 \pm 0.11$ & $0.17 \pm 0.14$ & $147.20 \pm 42.23$ & $58.4 \pm 10.5$ \\
2011 & $23.5 \pm 1.7$ & $7.7 \pm 1.6$ & $6.90 \pm 0.31$ & $0.21 \pm 0.04$ & $136.15 \pm 49.82$ & $47.6 \pm 13.8$ \\
2012 & $22.9 \pm 1.4$ & $8.5 \pm 1.8$ & $6.53 \pm 0.37$ & $0.18 \pm 0.05$ & $122.35 \pm 50.13$ & $48.3 \pm 12.4$ \\
\hline
\end{tabular}


Table 2. Prevalence (number of amphibian sampled) and infection level (mean of zoospores \pm SD) of $B d$ in study areas per year. CA: cultivated area. UCA: uncultivated area.

\begin{tabular}{lccc}
\hline & $\mathbf{2 0 1 0}$ & $\mathbf{2 0 1 1}$ & $\mathbf{2 0 1 2}$ \\
\hline Prevalence of $\boldsymbol{B d}$ & & & \\
CA & $0.73(152)$ & $0.20(149)$ & $0.17(147)$ \\
UCA & $0.95(165)$ & $0.39(172)$ & $0.34(173)$ \\
Infection level & & & \\
CA & $366.91 \pm 185.04$ & $3.76 \pm 48.89$ & $4.02 \pm 26.83$ \\
UCA & $767.02 \pm 143.28$ & $12.87 \pm 33.28$ & $4.25 \pm 39.44$ \\
\hline
\end{tabular}

0.05) (Table 2). The infection level decreased significantly during 2011 and 2012 according to Tukey's post hoc analysis $(p<0.05)$. The effect of the species also was significant $(F=5.79, d f=$ 2-911, $p<0.05)$. Leptodactylus latrans was the most highly infected species (Tukey's post hoc analysis: $p<0.05$ ) (Figure 3). The temperatures of the ponds also affected the infection level of $B d(F=29.21, d f=1-911, p<0.05)$.

The models conducted to test differences in patterns of $B d$ among species within the UCA (including Pseudis minuta) also documented a

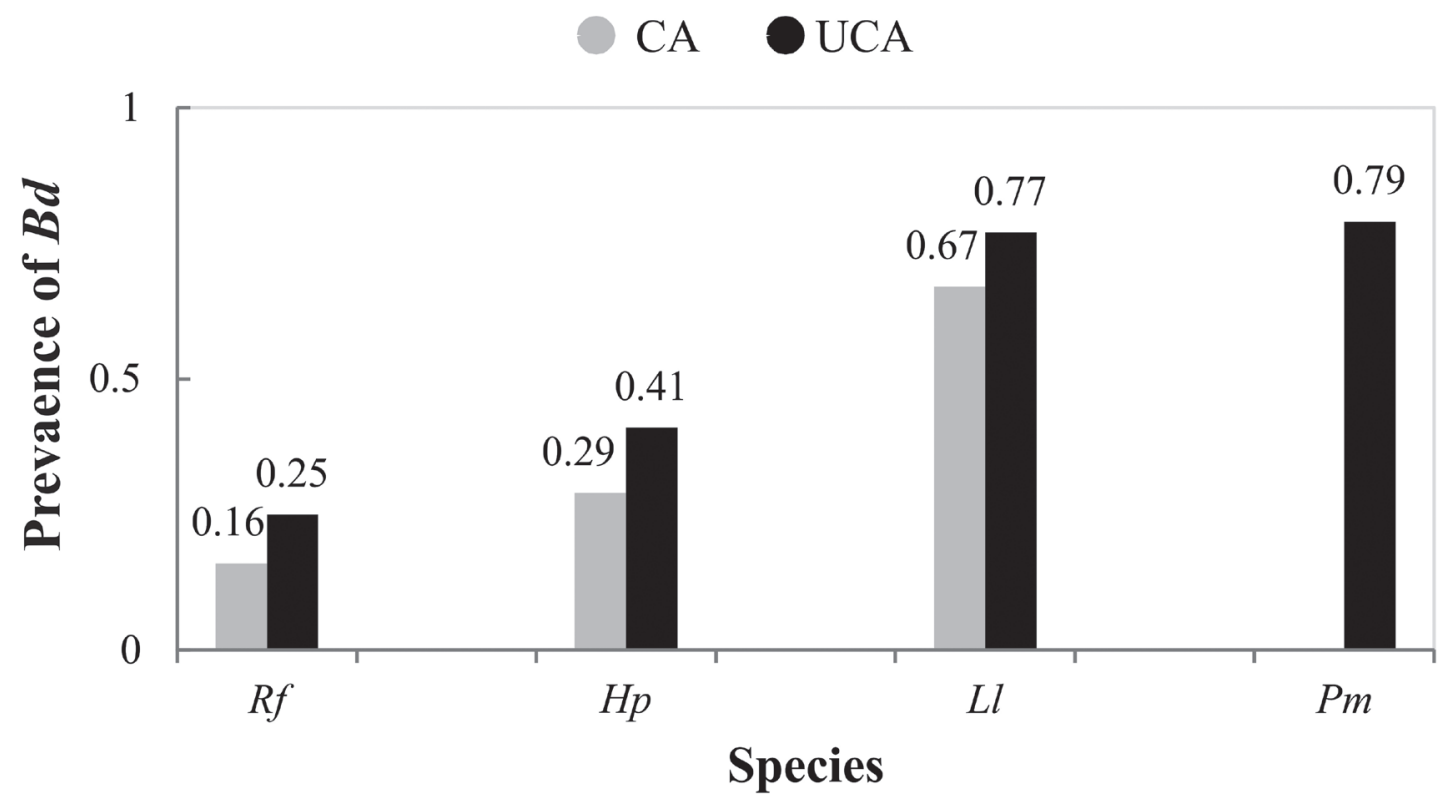

Figure 2. Prevalence of $B d$ for each studied species. CA: cultivated area. UCA: uncultivated area. Rf: Rhinella fernandezae. Hp: Hypsiboas pulchellus. LI: Leptodactylus latrans. Pm: Pseudis minuta. 
significant effect of prevalence $(Z=4.01, p<$ $0.05)$ and levels of $B d$ infection $(F=7.57, d f=$ 3-504, $p<0.05)$ on the species, with Leptodactylus latrans and $P$. minuta being the most highly infected species (Figure 2).

The correlation analysis showed a negative linear relationship between the SVL and infection level when considering all stages of Leptodactylus latrans from both areas $(\mathrm{r}=0.795, N=224)$, suggesting that infection intensity is associated to body size. The interaction between the study areas (CA and UCA) and SVL is statistically significant $(p<0.05)$; therefore, the model identified two regression equations (Figure 4).

Only two of the individuals sampled-both L. latrans juveniles-presented clinical signs of chytridiomycosis (e.g., lethargy and skin sloughing), with $B d$ infection levels of 1464 and 5610.8 zoospores. The rest of the population exhibited low to moderate infection intensities (Table 1), and appeared asymptomatic.

\section{Discussion}

Batrachochytrium dendrobatidis is one of the most host-generalist pathogens known, with

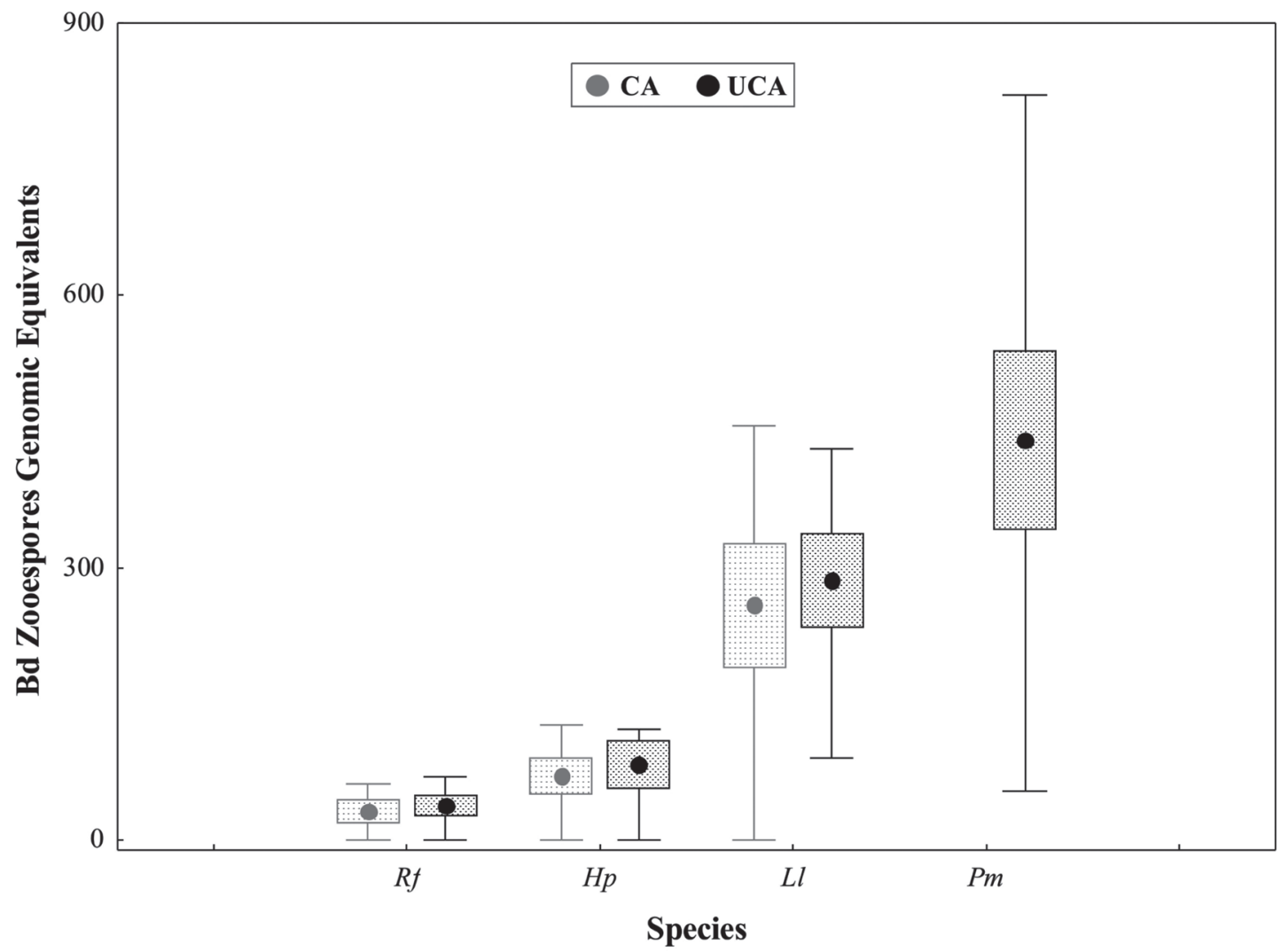

Figure 3. Infection level ( $B d$ zoospore genomic equivalent) for each studied species. CA: cultivated area. UCA: uncultivated area. Rf: Rhinella fernandezae. Hp: Hypsiboas pulchellus. Ll: Leptodactylus latrans. Pm: Pseudis minuta. Points represent the mean values and boxes the mean \pm SE. Whiskers represent the maximum and minimum range (without outliers values). 


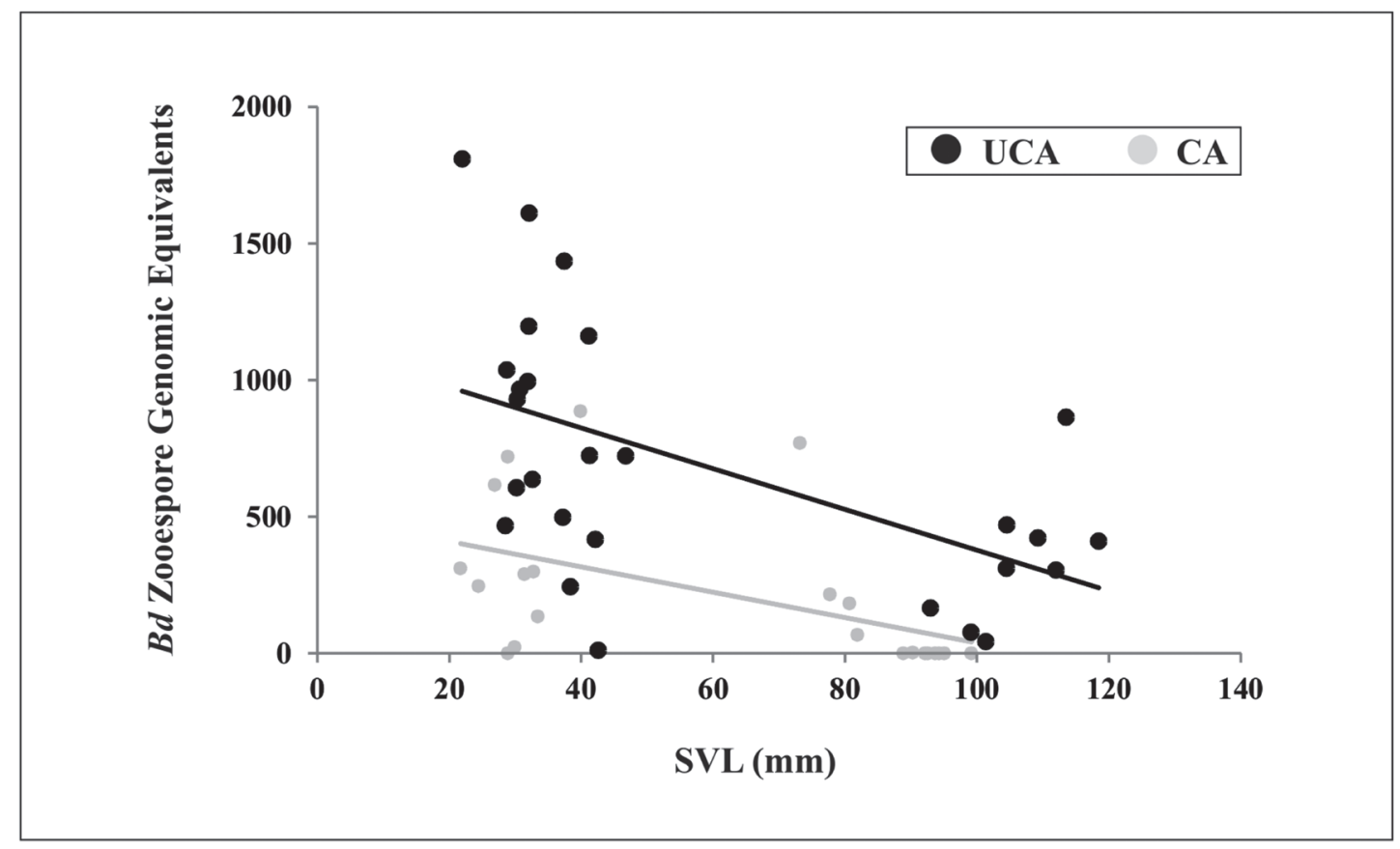

Figure 4. Linear correlation between the infection level ( $B d$ zoospore genomic equivalent) and body size (SVL) in Leptodactylus latrans juveniles and adults.

more than 350 amphibian host species documented (Fisher et al. 2009). All the species we studied, regardless their differences in habitat use, were $B d$-positive. This suggests that this pathogen is widely distributed in the Pampeana Phytogeographic Province, as predicted by Ghirardi et al. (2011).

It has been suggested that environmental stressors and diseases may act synergistically, and that sub-lethal levels of contaminants can suppress amphibian immune defenses, thereby allowing disease outbreak (Davidson and Knapp 2007, Davidson et al. 2007). However, we found lower prevalence and infection levels of $B d$ in anuran assemblages that inhabit the cultivated areas, despite the presence of agrochemicals such as glyphosate, endosulfan, chlorpyrifos and cypermethrin (Agostini et al. 2013). These results provide evidence based on fieldwork suggesting that, in areas where agrochemicals are used, $B d$ growth might be compromised, reducing the risk of chytridiomycosis in amphibians, and supporting findings from laboratory experiments (Hanlon and Parris 2012, McMahon et al. 2013).

Habitat loss has a negative association with $B d$ occurrence, prevalence, and infection levels in tropical anuran populations (Becker and Zamudio 2011, Murrieta-Galindo et al. 2014). These authors suggested that a potential explanation for the lower $B d$ infection risk in disturbed habitats could be the lower hostspecies richness and density. In recent years, the cultivated area has experienced a significant habitat loss related to increasing horticultural activity (Garcia 2010). This area have lower anuran species richness and the populations have lower densities compared to the uncultivated 
area (Agostini 2013). In fact, after an exhaustive monitoring, we could not confirm the occurrence of Pseudis minuta in any cultivated agroecosystem. Thus, habitat alteration and decreased host density may also contribute to the observed lower incidence of $B d$ in an area that also is disturbed by agrochemicals. It is yet not clear whether habitat disturbance, pesticide use (with their particular effects in hosts), and $B d$ are acting independently or synergistically. These complex interactions merit further investigation.

The temperatures of the ponds was associated with the patterns of $B d$ infection. The observed decrease of $B d$ prevalence and infection levels with time (2010-2012) may be related to a drastic period of drought and increased temperature that occurred in the region during 2011 and 2012 (INTA 2014). Cumulative rainfall (spring-summer) until February 2010 was 1010 $\mathrm{mm} /$ year, whereas values only reached $522 \mathrm{~mm} /$ year in 2011 and $465 \mathrm{~mm} /$ year in 2012. In addition, an increase of almost $1^{\circ} \mathrm{C}$ in average monthly temperature was registered during 2011 and 2012 in the Argentinean pampa (INTA 2014). As a consequence, the water temperature in our study sites increased from $18.6^{\circ} \mathrm{C}( \pm 1.6)$ in 2010 to $23.55^{\circ} \mathrm{C}( \pm 1.8)$ in 2011 and $23.1^{\circ} \mathrm{C}( \pm$ 2.9 ) in 2012. Additionally, many ponds from the cultivated and uncultivated areas were dry for most of the summer in the last two years of the study (Agostini 2013). These climatic conditions are expected to be unfavorable for $B d$ survival because this fungus prefers cooler temperatures for optimal growth and requires water for zoospore release and transmission (Longcore et al. 1999, Piotrowski et al. 2004). Population monitoring at our study sites revealed fewer anuran reproductive events during these dry periods and larval survival was compromised (Agostini 2013). Apparently, this results in lower host densities are consistent with predictions from density-dependent models that anticipate a consequent reduction in disease risk (Briggs et al. 2010).

It seems likely that additional factors other than land use are affecting the patterns of $B d$ infection that we found. Previous studies conducted in the area have reported low richness of macrophytes, and high nutrient and pesticide concentrations in ponds and streams from cultivated sites (Ronco et al. 2008, Mugni et al. 2010, 2011, Agostini 2013). It may be possible that such factors are affecting, directly or indirectly, the $B d$-amphibian dynamic. Nevertheless, they are undoubtedly a consequence of land use, and any possible interaction would support the results obtained in this study regarding to the effects of land use in the patterns of $B d$ infection.

The infection patterns also differed interspecifically. Those with aquatic habits (Leptodactylus latrans and Pseudis minuta) had high prevalence and infection levels of $B d$. These results concur with predictions and findings for other diverse amphibian assemblages (Lips et al. 2003, Bielby et al. 2008), and may be explained by the increased probability of contact with the $B d$ zoospores that represent the infectious stage of this pathogen (Longcore et al. 1999).

Another interesting finding of our work is that juvenile Leptodactylus latrans had significantly higher $B d$ prevalence and infection levels than the adults. These results are consistent with those found for other anurans and suggest that juveniles represent a critical stage for $B d$ dynamics in host populations (Woodhams et al. 2007, Longo and Burrowes 2010). Tadpoles of $L$. latrans are aquatic, form aggregations of several developmental stages, and remain gregarious until completing the metamorphosis. This behavior may explain the high $B d$ prevalence and level of infection in juveniles, because tadpoles can transmit $B d$ to others as well as to post-metamorphic individuals (Nichols et al. 2001, Rachowicz and Vredenburg 2004).

To our knowledge, we present the first study from South America on the infection patterns of $B d$ in anuran assemblages associated to agroecosystems with different degrees of anthropogenic disturbance. High infection prevalence in all species studied, regardless of 
site, suggests that this pathogen is widely distributed in the region. From a conservation standpoint, our results may seem paradoxical because they show that ponds in cultivated areas, with the most (chemical) disturbance, had a lower risk of $B d$ infection, and thus would be "good" for the anurans. However, we must note that the anurans from cultivated sites are also the most affected by agricultural practices, presenting morphological abnormalities (Agostini et al. 2013), compromised body condition, enzymatic alterations (Brodeur et al. 2011), and high larval mortalities caused by pesticide exposures (Agostini 2013).

Research in the past decade has shown that the response of anuran communities to $B d$ infection is complex, and many synergies with abiotic and biotic factors may be involved (Fisher et al. 2009, Venesky et al. 2014). Thus, we encourage interdisciplinary and international scientific collaborations that aim to study amphibian communities within a time frame long enough to detect in the wild, and decipher experimentally, key multi-factorial interactions. Such knowledge is needed to elucidate conservation and management practices that can help halt the current amphibian crisis.

\section{Acknowledgments}

The authors wish to thank Pablo Saibene, Ignacio Roesler and Regina Draghi, for assistance in the field, Alejandra Alicea and Anel Gonzalez for help in molecular $B d$ diagnosis at UPR, and Conor O' Donell for editorial suggestions. This study was funded by CREOI Foundation and Neotropical Grassland Conservancy in Argentina, and by Proyecto Coqui in Puerto Rico.

\section{References}

Agostini, M. G. 2013. Ecotoxicología de anfibios en agroecosistemas de la Región Pampena. Unpublished Ph.D. Dissertation. Universidad Nacional de La Plata, Argentina.
Agostini, M. G., G. S. Natale, and A. E. Ronco. 2009. Impact of endosulphan and cypermethrin mixture on amphibians under field use for biotech soya bean production. International Journal of Environment and Health 3: 379-389.

Agostini, M. G., F. Kacoliris, P. Demetrio, G. S. Natale, C. Bonetto, and A. E. Ronco. 2013. Abnormalities in amphibian populations inhabiting agroecosystems in Northeastern Buenos Aires province, Argentina. Diseases of Aquatic Organisms 104: 163-171.

Becker, C. G. and K. R. Zamudio. 2011. Tropical amphibian populations experience higher disease risk in natural habitats. Proceedings of National Academy of Science USA 108: 9893-9898.

Berger, L., R. Speare, and L. F. Skerratt. 2005. Distribution of Batrachochytrium dendrobatidis and pathology in the skin of green tree frogs Litoria caerulea with severe chytridiomycosis. Diseases of Aquatic Organisms 68: 65-70.

Berger, L., R. Speare, P. Daszak, D. E. Green, A. A. Cunningham, C. L. Goggin, R. Slocombe, M. A. Ragan, A. D. Hyatt, K. R. McDonald, H. B. Hines, K. R. Lips, G. Marantelli, and H. Parkers. 1998. Chytridiomycosis causes amphibian mortality associated with population declines in the rain forests of Australia and Central America. Proceedings of National Academy of Science USA 95: 9031-9036.

Bielby, J., N. Cooper, A. A. Cunningham, T. W. J. Garner, and A. Purvis. 2008. Predicting susceptibility to future declines in the world's frogs. Conservation Letters 1: $82-90$.

Bindraban, P. S., A. C. Franke, D. O. Ferraro, C. M. Ghersa, L. A. P. Lotz, A. Nepomuceno, M. J. M. Smulders, and C. C. M. van de Wiel. 2009. GM-Related Sustainability: Agro-ecological Impacts, Risks and Opportunities of Soy Production in Argentina and Brazil. Wageningen. Plant Research International B. V. 50 pp.

Blaustein, A. R., S. S. Gervasi, P. T. J. Johnson, J. T. Hoverman, L. K. Belden, P. W. Bradley, and G. Y. Xie. 2012. Ecophysiology meets conservation: understanding the role of disease in amphibian population declines. Philosophical Transactions of Royal Society B 367: 1688-1707.

Boyle, D. G., D. B. Boyle, V. Olsen, J. A. T. Morgan, and A. D. Hyatt. 2004. Rapid quantitative detection of chytridiomycosis (Batrachochytrium dendrobatidis) in amphibian samples using real-time Taqman PCR assay. Diseases of Aquatic Organisms 60: 141-148.

Briggs, C .J., R. A. Knapp, and V. T. Vredenburg. 2010. Enzootic and epizootic dynamics of the chytrid fungal 
pathogen of amphibians. Proceedings of National Academy of Science USA 107: 9695-9700.

Brodeur, J. C., R. P. Suarez, G. S. Natale, A. E. Ronco, and M. E. Zaccagnini. 2011. Reduced body condition and enzymatic alterations in frogs inhabiting intensive crop production areas. Ecotoxicology and Environmental Safety 74: 1370-1380.

Burrowes, P. A., R. L. Joglar, and D. E. Green. 2004. Potential causes for amphibian declines in Puerto Rico. Herpetologica 60: 141-154.

Burrowes, P. A., A. V. Longo, R. L. Joglar, and A. A. Cunningham. 2008. Geographic distribution of Batrachochytrium dendrobatidis in Puerto Rico. Herpetological Review 39: 321-324.

Cabrera, A. L. and A. Willink (eds.). 1973. Biogeografía de América Latina. Washington DC. Serie de Biología, Monografía 13 OEA. 132 pp.

Carey, C. and M. A. Alexander. 2003. Climate change and amphibian declines: is there a link? Diversity and Distributions 9: 111-121.

Cei, J. M. 1980. Amphibians of Argentina. Monitore Zoologico Italiano, Italian Journal of Zoology, Monografia 2. Università degli Studi di Firenze. 609 pp.

Cheng, T. L., S. M. Rovito, D. B. Wake, and V. T. Vredenburg. 2011. Coincident mass extirpation of neotropical amphibians with the emergence of the infectious fungal pathogen Batrachochytrium dendrobatidis. Proceedings of National Academy of Science USA 108: 9502-9508.

Crawley, M. J. (ed.). 2007. The R Book. Chichester. John Wiley \& Sons Ldt. 942 pp.

Davidson, C. and R. A. Knapp 2007. Multiple stressors and amphibian declines: dual impacts of pesticides and fish on yellow-legged frogs. Ecological Application 17: 587-597.

Davidson, C., M. F. Benard, H. B. Shaffer, J. M. Parker, C. O'Leary, J. M. Conlon, and L. A. Rollins-Smith. 2007. Effects of chytrid and carbaryl exposure on survival, growth and skin peptide defenses in foothill yellowlegged frogs. Environmental Science \& Technology 41: 1771-1776.

Doddington, B. J., J. Bosch, J. A. Oliver, N. C. Grassly, G. Garcia, B. R. Smith, T. W. Garner, and M. C. Fisher. 2013. Context-dependent amphibian host population response to an invading pathogen. Ecology 94: 17951804.

Fisher, M. C., T. W. Garner, and S. F. Walker. 2009. Global emergence of Batrachochytrium dendrobatidis and amphibian chytridiomycosis in space, time, and host. Annual Review of Microbiology 63: 291-310.

Gallant, A. L, R. W. Klaver, G. S. Casper, and M. J. Lannoo. 2007. Global rates of habitat loss and implications for amphibian conservation. Copeia 2007: 967-979.

Garcia, M. 2010. Inicios, consolidación y diferenciación de la horticultura platense. Pp. 69-86 in A. Svetlitza de Nemirovsky (ed.), Globalización y Agricultura Periurbana en la Argentina. Escenarios, Recorridos y Problemas. Buenos Aires. FLACSO, Serie Monografías 1.

Ghirardi, R., M. G. Perotti, M. M. Steciow, M. L. Arellano, and G. S. Natale. 2011. Potential distribution of Batrachochytrium dendrobatidis in Argentina: implications in amphibian conservation. Hydrobiologia 659: 111-115.

Hanlon, S. M. and M. J. Parris. 2012. The impact of pesticides on the pathogen Batrachochytrium dendrobatidis independent of potential hosts. Archives of Environmental Contamination of Toxicology 63: 137143.

Herrera, L. P., J. L. Panigatti, M. P. Barral, and D. E. Blanco. 2013. Biofuels in Argentina. Impacts of Soybean Production on Wetlands and Water. Buenos Aires. Fundación para la Conservación y el Uso Sustentable de los Humedales, Wetlands International. 104 pp.

Heyer, R. W., M. A. Donnelly, R. W. McDiarmid, L. C. Hayek, and M. S Foster (eds.). 1994. Measuring and Monitoring Biological Diversity. Standard Methods for Amphibians. Washington DC. Smithsonian Institution Press. 384 pp.

Hurtado, M. A., J. E. Giménez, and M. G. Cabral (eds.). 2006. Análisis Ambiental del Partido de La Plata. Globalización y Agricultura Periurbana en la Argentina. Buenos Aires. Consejo Federal de Inversiones. 197 pp.

Hyatt, A. D., D. G. Boyle, V. Olsen, D. B. Boyle, L. Berger, D. Obendorf, A. Dalton, K. Krieger, M. Heros, H. Hines, R. Phillott, R. Campbell, G. Marantelli, F. Gleason, and A. Coiloing. 2007. Diagnostic assays and sampling protocols for the detection of Batrachochytrium dendrobatidis. Diseases of Aquatic Organisms 73: 175-192.

INTA. 2014. Instituto Nacional de Tecnología Agropecuaria. Electronic Database accessible at http://rian.inta.gov.ar/ agua/informes.aspx. Captured on 15 October 2014.

Lips, K. R., J. D. Reeve, and L. R. Witters. 2003. Ecological traits predicting amphibian population declines in Central America. Conservation Biology 17: 1078-1088.

Lips, K. R., F. Brem, R. Brenes, J. D. Reeve, R. A. Alford, J. Voyles, C. Carey, L. Livo, A. P. Pessier, and J. P. 
Collins. 2006. Emerging infectious disease and the loss of biodiversity in a Neotropical amphibian community. Proceedings of National Academy of Science USA 103: 3165-3170.

Longcore, J. E., A. P. Pessier, and D. K. Nichols. 1999. Batrachochytrium dendrobatidis gen. et sp. nov., a chytrid pathogenic to amphibians. Mycologia 91: 219227.

Longo, A. V. and P. A. Burrowes. 2010. Persistence with Chytridiomycosis does not assure survival of directdeveloping frogs. EcoHealth 7: 185-195.

Longo, A. V., P. A. Burrowes, and R. L. Joglar. 2010. Seasonal patterns of Batrachochytrium dendrobatidis infection in direct-developing frogs suggest a mechanism for persistence in enzootic conditions. Diseases of Aquatic Organisms 92: 253-260.

Longo, A. V., D. Rodriguez, D. Silva Leite, L. F.Toledo, C. M. Almeralla, P. A. Burrowes, and K. R. Zamudio. 2013. ITS1 copy number varies among Batrachochytrium dendrobatidis strains: implications for qPCR estimates of infection intensity from Field-Collected amphibian skin swabs. PLOS ONE 8: e59499.

McMahon, T. A., L. A. Brannelly, M. W. H. Chatfield, P. T. J. Johnson, M. B. Joseph, V. J. McKenzie, C. L. Richards-Zawacki, M. D. Venesky, and J. R. Rohr. 2013. Chytrid fungus Batrachochytrium dendrobatidis has nonamphibian hosts and releases chemicals that cause pathology in the absence of infection. Proceedings of the National Academy of Sciences USA 110: 210-215.

Mugni, H., A. E. Ronco, and C. Bonetto. 2011. Insecticide toxicity to Hyalella curvispina in runoff and stream water within a soybean farm (Buenos Aires, Argentina). Ecotoxicology and Environmental Safety 74: 350-354.

Mugni, H., P. Demetrio, D. Marino, A. Ronco, and C. Bonetto. 2010. Toxicity persistence following an experimental Cypermethrin and Chlorpyrifos application in pampasic surface waters (Buenos Aires, Argentina). Bulletin of Environmental Contamination and Toxicolgy 84: 524-528.

Murray, K. A., L. F. Skerratt, S. Garland, D. Kriticos, and H. McCallum. 2013. Whether the weather drives patterns of endemic amphibian chytridiomycosis: a pathogen proliferation approach. PLOS ONE 8: e61061.

Murrieta-Galindo, R., G. Parra-Olea, A. González-Romero, F. López-Barrera, and V. T. Vredenburg. 2014. Detection of Batrachochytrium dendrobatidis in amphibians inhabiting cloud forests and coffee agroecosystems in central Veracruz, Mexico. European Journal Wildlife Research 60: 431-439.
Nichols, D. K., E. W. Lamirande, A. P. Pessier, and J. E. Longcore. 2001. Experimental transmission of cutaneous chytridiomycosis in dendrobatid frogs. Journal of Wildlife Diseases 37: 1-11.

Piotrowski, J. S., S. L. Annis, and J. E. Longcore. 2004. Physiology of Batrachochytrium dendrobatidis, a chytrid pathogen of amphibians. Mycologia 96: 9-15.

R Development Core Team. 2014. R: A Language and Environment for Statistical Computing. R Foundation for Statistical Computing. Version 3.1-108. URL: http:// www.r-project.org/.

Rachowicz, L. J. and V. T. Vredenburg. 2004. Transmission of Batrachochytrium dendrobatidis within and between amphibian life stages. Diseases of Aquatic Organisms 61: 75-83.

Rohr, J. R., T. R. Raffel, J. M. Romansic, H. McCallum, and P. J. Hudson. 2008. Evaluating the links between climate, disease spread, and amphibian declines. Proceedings of National Academy of Science USA 105: 17436-17441.

Ronco, A. E., P. Carriquiriborde, G. S. Natale, M. L. Martin, H. Mugni, and C. Bonetto. 2008. Integrated approach for the assessment of biotech soybean pesticides impact on low order stream ecosystems of the Pampasic region. Pp. 209-239 in J. Chen and C. Guô (eds.), Ecosystem Ecology Research Trends. New York. Nova Science Publishers.

Solbrig, O.T. 1997. Towards a sustainable pampa agriculture: past performance and prospective analysis. Harvard. DRCLAS Working Papers on Latin America Series. 51 pp.

Soriano, A. 1991. Río de la Plata Grasslands. Pp. 367-407 in R. T. Coupland (ed.), Natural Grasslands: Introduction and Western Hemisphere. Serie Ecosystems of the World 8A. Amsterdam. Elsevier.

VassarStats. 2014. Website for Statistical Computation. URL http://vassarstats.net.

Venesky, M. D., X. Liu, E. L. Sauer, and J. R. Rohr. 2014. Linking manipulative experiments to field data to test the dilution effect. Journal of Animal Ecology 83: 557565.

Viglizzo, E. F., F. Lértora, A. J. Pordomingo, J. N. Bernardos, Z. E. Roberto, and H. del Valle. 2001. Ecological lessons and applications from one century of low external-input farming in the pampas of Argentina. Agriculture, Ecosystems \& Environment 83: 65-81.

Wise, R. S., S. L. Rumschlag, and M. D. Boone. 2014. Effects of amphibian chytrid fungus exposure on 
American toads in the presence of an insecticide. Environmental Toxicology and Chemistry 33: 25412544.

Woodhams, D. C., L. A. Rollins-Smith, R. A. Alford, M. A. Simon, and R. N. Harris. 2007. Innate immune defenses of amphibian skin: antimicrobial peptides and more. Animal Conservation 10: 425-428.
Zar, J.H. (ed.). 2010. Biostatistical Analysis. $5^{\text {th }}$ edition.New Jersey. Prentice Hall. 944 pp.

Zuur, A. F., E. N. Ieno, N. J .Walker, A. A. Saveliev, and G. M. Smith (eds.). 2009. Mixed Effects Models and Extensions in Ecology with R. New York. Springer. 574 pp.

Editor: Vanessa K. Verdade 